\title{
Change of Extracellular Matrix of Human Vocal Fold Fibroblasts by Vibratory Stimulation
}

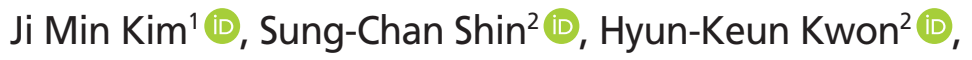 \\ Yong-II Cheon ${ }^{2}$ (D) Jung Hoon Ro ${ }^{3}$ (D), and Byung-Joo Lee ${ }^{2}$ (i) \\ ${ }^{1}$ Pusan National University Medical Research Institute, Pusan National University, Yangsan, Korea \\ 2Department of Otorhinolaryngology-Head and Neck Surgery, College of Medicine, Pusan National University and Biomedical Research Institute, \\ Pusan National University Hospital, Busan, Korea \\ ${ }^{3}$ Department of Biomedical Engineering, College of Medicine, Pusan National University, Busan, Korea
}

진동이 성대세포주의 세포외기질 변화에 대한 연구

김지민 ${ }^{1}$, 신성찬 $^{2}$, 권현근 $^{2}$, 천용일 2 , 노정훈 ${ }^{3}$, 이병주 ${ }^{2}$

부산대학교 의학연구원, ${ }^{1}$ 부산대학교 의과대학 이비인후과학교실, ${ }^{2}$ 부산대학교 의과대학 의용공학교실 ${ }^{3}$

Background and Objectives During speech, the vocal folds oscillate at frequencies ranging from $100-200 \mathrm{~Hz}$ with amplitudes of a few millimeters. Mechanical stimulation is an essential factor which affects metabolism of human vocal folds. The effect of mechanical vibration on the cellular response in the human vocal fold fibroblasts cells (hVFFs) was evaluated.

Materials and Method We created a culture systemic device capable of generating vibratory stimulations at human phonation frequencies. To establish optimal cell culture condition, cellular proliferation and viability assay was examined. Quantitative real time polymerase chain reaction was used to assess extracellular matrix (ECM) related and growth factors expression on response to changes in vibratory frequency and amplitude. Western blot was used to investigate ECM and inflammation-related transcription factor activation and its related cellular signaling transduction pathway.

Results The cell viability was stable with vibratory stimulation within $24 \mathrm{~h}$. A statistically significant increase of ECM genes (collagen type I alpha 1 and collagen type I alpha 2) and growth factor [transforming growth factor $\beta 1$ (TGF- $\beta 1$ ) and fibroblast growth factor 1 (FGF-1)] observe under the experimental conditions. Vibratory stimulation induced transcriptional activation of NF- $\kappa B$ by phosphorylation of p65 subunit through cellular Mitogen-activated protein kinases activation by extracellular signal regulated kinase and p38 mitogen-activated protein kinases (MAPKs) phosphorylation on hVFFs.

Conclusion This study confirmed enhancing synthesis of collagen, TGF- $\beta 1$ and FGF was testified by vibratory stimulation on hVFFs. This mechanism is thought to be due to the activation of $\mathrm{NF}-\kappa \mathrm{B}$ and MAPKs. Taken together, these results demonstrate that vibratory bioreactor may be a suitable alternative to hVFFs for studying vocal folds cellular response to vibratory vocalization.

Keywords Vocal fold fibroblasts; Vibratory bioreactor; Extracellular matrix; Collagen.

\section{서 론}

인간의 성대는 상피층(epithelium), 고유층(lamina propria) 및 성대 근육(vocalis
Received November 16, 2020

Revised December 10, 2020

Accepted December 10, 2020

Corresponding Author

Byung-Joo Lee, MD, PhD

Department of Otorhinolaryngology-

Head and Neck Surgery,

College of Medicine,

Pusan National University and

Biomedical Research Institute,

Pusan National University Hospital,

179 Gudeok-ro, Seo-gu,

Busan 49241, Korea

Tel +82-51-240-7528

Fax+82-51-240-2162

E-mail voiceleebj@gmail.com

\section{ORCID iDs}

Ji Min Kim (1)

https://orcid.org/0000-0002-3608-765X Sung-Chan Shin (D)

https://orcid.org/0000-0003-2329-0648

Hyun-Keun Kwon (D)

https://orcid.org/0000-0003-4089-8639

Yong-II Cheon (D)

https://orcid. org/0000-0003-0288-0542

Jung Hoon Ro (D)

https://orcid.org/0000-0002-5203-5956

Byung-Joo Lee (D)

https://orcid.org/0000-0001-7091-6688

This is an Open Access article distributed under the terms of the Creative Commons Attribution Non-Commercial License (https://creativecommons.org/ licenses/by-nc/4.0) which permits unrestricted non-commercial use, distribution, and reproduction in any medium, provided the original work is properly cited. 
muscle)으로 구성되며, 폐의 공기 흐름을 음파로 변환시킬 수 있는 특수한 기관이다[1]. 성대의 고유층은 천층(superficial layer), 중간층(intermediate layer), 심층(deep layer)으로 구 성된 계층 구조를 가지고 있으며, 주로 콜라겐 섬유(collagen fiber)와 엘라스틴(elastin) 그리고 히알루론산(hyaluronic acid)으로 구성되어 있다. 성대는 정상적인 발성을 하기 위해 $100 \sim 300 \mathrm{~Hz}$ 범위의 기본 주파수에서 일정하게 진동한다[2]. 성대의 진동 움직임은 음성을 생성하는 데 없어서는 안 될 뿐 만 아니라 부분적으로 성대의 발달과 성숙에 기여한다[3]. 그 러나 성대 발달 및 음성을 조절하는 메커니즘은 아직 완전히 연구되어 있지 않다.

성대 고유층의 점탄성을 유지하기 위해서는 세포외기질의 조성이 중요하다. 이 중 가장 중요한 성분 중의 하나가 콜라겐 이다. 성대 반흔은 일반적으로 성대 고유층에 콜라겐이 매우 증가하고, 증가된 콜라겐이 비정상적인 구조로 구성되어 성대 의 점탄성을 감소시켜서 성대의 진동을 방해하고 조직의 강 도를 증가시킨다[4]. 콜라겐 이외의 여러 가지 다른 세포외기 질 등에 대한 연구가 있으나, 히알루론산, 피브로넥틴(fibronectin), 데코인(decorin) 등의 변화가 연구자에 따라 다소 차 이가 있는데[5] 이러한 차이는 실험동물 종, 성대 손상의 정도 와 손상 유발 방법, 그리고 세포외기질을 측정하는 방법의 차 이로 인한 것으로 생각된다.

세포외기질의 구성과 특성은 기계적 환경에 의해 조절된다 고 알려져 있다[6,7]. 조직 공학 관점에서 생리학적으로 관련 된 기계적 자극에 노출되면 세포 분화와 변화가 촉진된다. 평 활근세포나 섬유아세포에서 압력과 같은 기계적인 자극은 조직 특이적인 세포외기질의 발현을 유도하여 조직 특이적인 특성을 증가시킨다[8,9]. 적절한 기계적 자극은 세포 분화와 조직 발달 및 성숙을 촉진하지만, 음성 남용과 같은 과도한 기 계적 자극은 성대 고유층의 구조, 구성 및 기계적 특성의 변 경을 초래하여 성대 결절과 용종(polyp)을 만들기도 한다[10]. 성대는 인체의 기관 중에서 $100 ~ 300 \mathrm{~Hz}$ 의 진동이 발생하는
특이적인 기관이다. 그러므로 성대에서 발생하는 진동은 성 대 고유층 및 성대 섬유아세포의 세포외기질에 영향을 줄 것 으로 생각된다. 그러나 성대에서 발생하는 진동이 성대 고유 층 또는 성대 섬유아세포의 세포외기질에 미치는 영향에 대 한 연구는 아직 미비하다.

생물반응기(bioreactor)는 in vitro 연구에서 세포 또는 조 직 성장을 위한 특정한 생리적 환경을 시뮬레이션하도록 설 계된 장비이다. 성대 조직 공학의 경우 발성 성대의 기계적 환 경, 즉 진동을 재현하는 것이 특히 중요하다. 이상적인 생물반 응기는 진동 신호를 배양 세포에 효과적으로 전달하여 진동 의 주파수, 진폭 및 지속 시간을 쉽게 제어할 수 있어야 한다. 여러 가지 형태의 복잡한 생물반응기가 발표되었다. Titze 등 [11]은 세포 내 기질 단백질의 세포 생산을 자극하기 위해 정 적 스트레치와 고주파 $(20 \sim 200 \mathrm{~Hz})$ 진동을 결합한 성대 생물 반응기를 고안하였다. 본 연구에서는 소형 모터(motor)를 장 착하여 단순하게 제작된 생물반응기를 이용하여 인간 성대 섬유아세포에서 진동에 의한 세포외기질의 변화와 그 기전을 조사하였다.

\section{대상 및 방법}

\section{진동 생물반응기}

연구자는 작은 모터의 회전 에너지를 진동 에너지로 변경하 여 진동 자극을 생성할 수 있는 생물반응기를 자체적으로 제 작하였다. 개발한 생물반응기는 진동을 유발하는 동력 모터 와 세포 배양을 위한 표준 $75 \mathrm{~T}$ 세포 플라스크 및 플라스크를 고정하기 위한 원주 방향으로 배열된 스폰지로 구성된다. 진 동 자극 시 세포를 $37^{\circ} \mathrm{C}$ 가 유지되는 세포 배양 환경을 만들 기 위하여 이 장치는 세포배양기 내에 설치할 수 있으며 외 부의 파형 발생기로 연결되어 주파수의 증폭 및 감소 등의 전 력 조절이 외부에서 가능하다(Fig. 1).
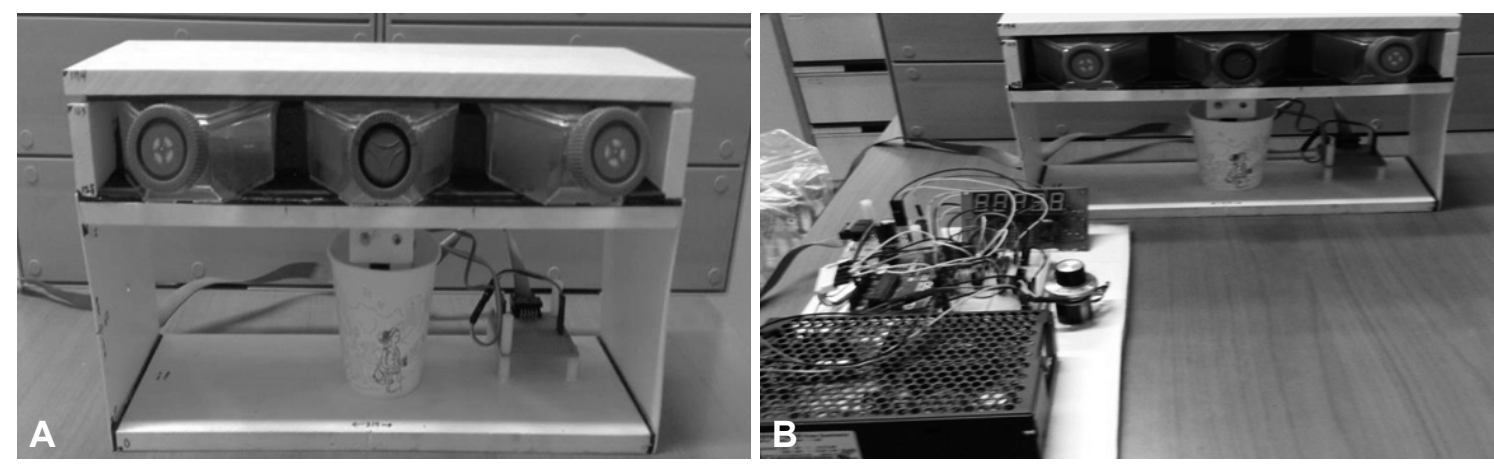

Fig. 1. Schematic of the developed bioreactor. The bioreactor unit consists of a vibration motor that induces vibration and a standard 75T cell flask for cell culture and a circumferentially arranged sponge to hold the flask (A). The bioreactor can be installed in the cell incubator and is connected to an external waveform generator to allow external power control such as amplification and reduction of frequency (B). 


\section{사람 성대 섬유아세포}

인간 성대 섬유아세포(human vocal fold fibrobloasts, $\mathrm{hVFFs}$ )는 위스콘신 매디슨 대학교 의과대학 이비인후과에 서 확립한 세포주를 사용하였다[12]. 배양액은 2일에 한 번씩 교체하고 9 15계대까지 세포 실험을 시행하였다. 진동 자극 을 위해 $\mathrm{hVFFs}$ 를 $8 \times 10^{6} / \mathrm{mL}$ 의 농도로 배양한 뒤 생물반응 기를 이용하여 성대 섬유아세포 진동 자극을 주었다. 진동 자 극의 조건은 50 200 Hz까지의 주파수를 조절하였고, 하루 $1 \sim 72$ 시간까지의 진동 노출 시간을 조정하였다. 진동 자극 없 이 실험군과 동일한 시간 동안 같은 조건으로 $37^{\circ} \mathrm{C}$ 세포배양 기에서 배양된 세포를 대조군으로 사용하였다.

세포의 형태, 세포 사멸과 활성도 및 세포 증식의 확인 진동 자극을 시행하기 전에 성대 섬유아세포가 플레이트에 제대로 부착(adhesion)되었는지 확인하고, 세포를 각각의 조 건으로 진동 자극을 시행한 후 광학현미경으로 세포들의 형 태 변화를 다시 관찰하였다. 또한, 진동 자극 후 세포의 세포 사멸 정도를 확인하기 위하여 3-(4,5-dimethylthiazol-2-yl)2,5-diphenyl-tetrazolium bromide(MTT) colorimetric reduction assay를 이용하였다. 진동 자극이 끝난 세포의 배지를 제거하고 $200 \mu \mathrm{L}$ 새 배지를 첨가하고 $50 \mu \mathrm{L} / \mathrm{well}(2 \mathrm{mg} / \mathrm{mL})$ MTT 시약을 처리하여 4시간 두었다. MTT 시약이 들어있는 배 지를 제거하고 dimethyl sulfoxide(DMSO, Sigma, Ronkonkoma, NY, USA)를 처리하여 천천히 흔들어준 후 formarzan 결정체를 용해시킨 후 microplate reader(EL800, BioTek, Winooski, VT, USA)로 $570 \mathrm{~nm}$ 에서 흡광도를 측정했다.

\section{실시간 중합효소연쇄반응검사}

세포를 각각의 조건으로 진동 자극을 시행한 후 얻어진 세 포를 phosphate-buffered saline로 세척하여 회수한 뒤 Trizol (Qiagen, Valencia, CA, USA), 클로로포름, 이소프로판올 시 스템을 사용하여 RNA를 추출하였다. RNA 침전물을 $75 \%$ 에 탄올로 세척하고, 상온에서 건조시킨 다음 diethylpyrocarbonate $(\mathrm{DEPC})$ 로 처리한 증류수에 녹였다. 정제된 RNA를 cDNA 합성을 위해 Nanodrop-1000 분광 광도계(Thermo Scientific, Wilmington, DE, USA)를 사용하여 RNA를 정량 화하고 AccuPower CycleScript RT Premix(Bioneer, Daejeon, Korea)를 사용하여 Peltier Thermal Cycler PTC-200 (Roche, Indianapolis, IN, USA)에서 $37^{\circ} \mathrm{C}$ 에서 1시간 동안 $\mathrm{cDNA}$ 를 합성하였다. NCBI BLAST를 사용하여 프라이머를 설계하였다. 정량적 중합효소연쇄반응검사(quantitative polymerase chain reaction, qPCR)은 SYBR Green PCR 프로 토콜(Applied Biosystems, Foster City, CA, USA)에 따라 수
행되었다. 각 샘플은 다섯 번 반복 실험하였으며; 반응 조건 은 $95^{\circ} \mathrm{C}$ 에서 10 분 $\left(1\right.$ 사이클), $95^{\circ} \mathrm{C}$ 에서 10 초, $60^{\circ} \mathrm{C}$ 에서 30 초 (40 사이클)로 증폭하였다. 유전자 특이적 PCR 산물은 $\mathrm{ABI}$ PRISM 7900 HT 서열 검출 시스템(PE Applied Biosystem, Norwalk, CT, USA)에 의해 지속적으로 측정하였다. 프라이 머 시퀀스는 Fig. 2와 같다.

\section{웨스턴 블랏(Western blot) 분석}

웨스턴 블랏 분석을 위해서 세포질과 핵을 분리한 단백질 을 웨스턴 버퍼와 함께 $95^{\circ} \mathrm{C}$ 의 온도에서 5 분 동안 반응시킨 후, $12 \%$ sodium dodecyl sulfate polyacrylamide gel electrophoresis를 통해 전기영동한 후 PVDF membrane(BioRad, Hercules, CA, USA)으로 단백질을 이동시켰다. PVDF membrane은 5\%의 탈지분유(BD Biosciences, San Jose, $\mathrm{CA}, \mathrm{USA})$ 에 담아 실온에서 1 시간 동안 반응시킨 후 anti-p65, anti-phospho p65(Santa Cruz Biotechnology, Dallas, TX, USA), anti-p38, anti-phospho p38, anti-ERK, anti-phospho ERK(Cell Signaling, Danvers, MA, USA) 등을 첨가하 여 $4^{\circ} \mathrm{C}$ 냉장에서 하룻밤 동안 반응시켰다. 그 후 horseradish peroxidase(HRP)-conjugated rabbit(1:5,000 희석; Bio-Rad) 또는 mouse(1:10,000 희석; $\mathrm{Bio}-\mathrm{Rad})$ 2차 항체로 실온에서 1시간 동안 반응시킨 후, ECL Advance Western blot detection kit(Amersham, Piscataway, NJ, USA)를 사용하여 peroxidase 활성을 밴드로 시각화하여 단백질 발현을 검출하였 다. 발광하여 X-ray film에 노출시켜 단백질 발현량을 확인 하였다.

\section{통계 분석}

본 실험에서 결과는 측정값의 평균ㅍ표준편차로 나타내었 고, 유의성 검증을 위해 Prism 7.0(GraphPad, San Diego, $\mathrm{CA}, \mathrm{USA}$ )를 이용하여 independent t-tests를 사용하여 각 실험군 간의 유의성을 분석하였고, 그 유의 수준은 $\mathrm{p}<0.05$

\begin{tabular}{|lll|}
\hline $\begin{array}{l}\text { COL1A1 } \\
\text { collagen, type I, alpha 1 }\end{array}$ & F & 5'-TCTGCGACAACGGCAAGGTG-3' \\
COL1A2 & R & 5'-GACGCCGGTGGTTCTTGGT-3' \\
collagen, type I, alpha 2 & F & 5'-GAGGGCAACAGCAGGTTCACTTA-3' \\
ELN & R & 5'-TCAGCACCACCGATGTCCAA-3' \\
elastin & F & 5'-CCGCTAAGGCAGCCAAGTATGGA-3' \\
HAS-1 & R & 5'-GCTCCAACCCCGTAAGTAGGAAT-3' \\
hyaluronan synthase 1 & F & 5'-TGTGACTCGGACACAAGGTTG-3' \\
TGF $\beta 1$ & R & 5'-GCCT CAAGAAACTGCTGCAA -3' \\
transforming growth factor $\beta 1$ & F & 5'-GAGGTGACCTGGCCACCATTCAT-3' \\
FGF1 & R & 5'-TCCGCAAGGACCTCGGCTGG-3 \\
fibroblast growth factors 1 & F & 5'-CAATGTTTGGGCTAAGACCTG-3' \\
$\beta$ actin & R & 5'-GGCTGTGAAGGTGGTGATTT-3' \\
beta actin & F & 5'-GTGGCCGAGGACTTTGATTG-3' \\
\hline
\end{tabular}

Fig. 2. Primer sequence. 


\section{JKSLP}

로 검정하였다.

\section{결 과}

진동 자극이 성대 섬유아세포의 형태와

세포 생존력에 미치는 영향

반복 자기 자극을 시행하기 전 진동 실험군과 대조군 모두 에서 세포들이 배양 플라스크 및 진동 자극 생물반응기 작동 시 정상적으로 부착하여 자라고 있음을 확인하고 실험을 수 행하였다. 진동 자극은 일상적인 음성 진동 자극 시의 진동 주 파수와 자극 시간을 바탕으로 구성하였다. 그 결과 진동 자극 후 성대 섬유아세포의 형태적인 변화는 $130 \mathrm{~Hz}, 6$ 시간의 진 동 자극에서는 차이가 없었다(Fig. 3A). 그러나 $100 \mathrm{~Hz}$ 실험 군에서 진동 노출 16 시간 이후 $50 \%(\mathrm{p}<0.001)$ 이하의 세포활 성도를 보였다(Fig. $3 B$ ). 반복 진동 자극이 성대 섬유아세포 에서 단시간에는 유의한 세포 활성도의 감소와 세포 독성을 보이지 않으나 48시간 이상 장시간 지속되면 세포 사멸을 유
도함을 의미한다.

\section{진동 자극이 성대 섬유아세포의 콜라겐 발현에 미치는 영향}

진동 자극에 따른 콜라겐과 엘라스틴, 히알루론산 등의 성 대 고유층을 구성하는 세포외기질의 변화에 대해 조사하였 다. 진동 주파수의 증가와 함께 콜라겐의 아형인 collagen type I alpha 1(COL1A1)과 collagen type I alpha 2(COL1A2)의 mRNA를 발현시켰으며 이는 100 130 Hz에서 가 장 높은 발현을 보였다 $(\mathrm{p}<0.05)$. 또한 $100 \mathrm{~Hz}$ 의 일정한 진동 자극을 다양한 시간으로 유발한 결과 COL1A1은 6시간 이후 $(\mathrm{p}<0.001), \mathrm{COL1A} 2$ 는 16 시간 $(\mathrm{p}<0.05)$ 에서 가장 높게 발현 되었다. COL1A1은 72시간까지 발현이 유지되며 COL1A2는 48시간 이후로는 그 발현이 줄어드는 것을 확인하였다(Fig. 4A). 다른 세포외기질인 hyaluronic acid synthase 1(HAS-1) 와 엘라스틴(elastin, ELN)의 mRNA 발현 역시 확인하였으 나, 본 연구에서는 대조군과 비교하여 진동 주파수와 진동 자
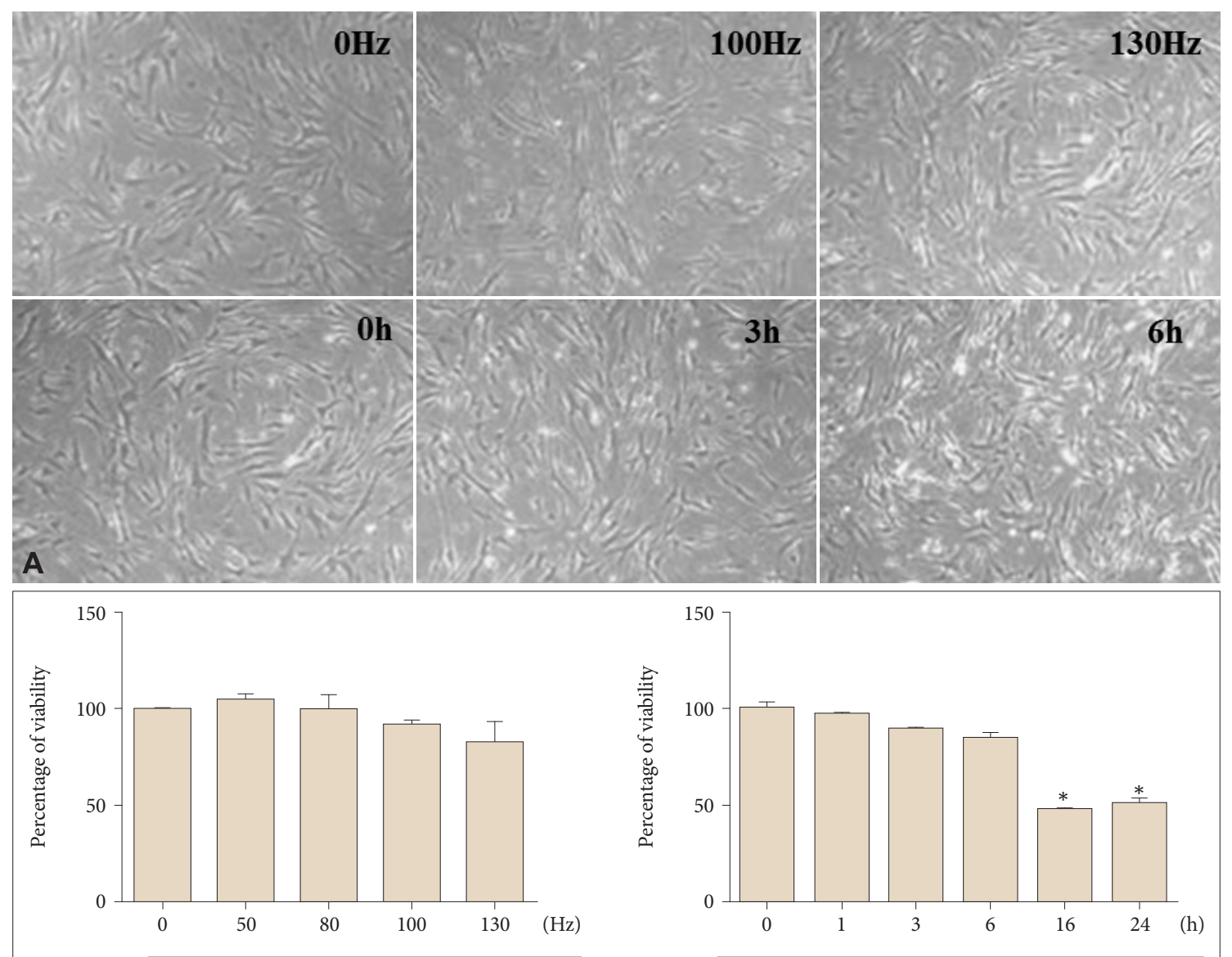

B

$6 \mathrm{~h}$

$100 \mathrm{~Hz}$

Fig. 3. Effects of vibratory stimulations on cellular viability in hVFFs. A: Cells were placed in a chamber with/without vibrating stimulation. Cellular morphology was no difference in hVFFs $(\times 100)$. B: Cell viability of hVFFs measured by MTT assay. MTT assay showed that the viability decreased to $70 \%$ or less after 16 hours with vibrating stimulation. ${ }^{*} p<0.001$. hVFF: human vocal fold fibrobloasts. 


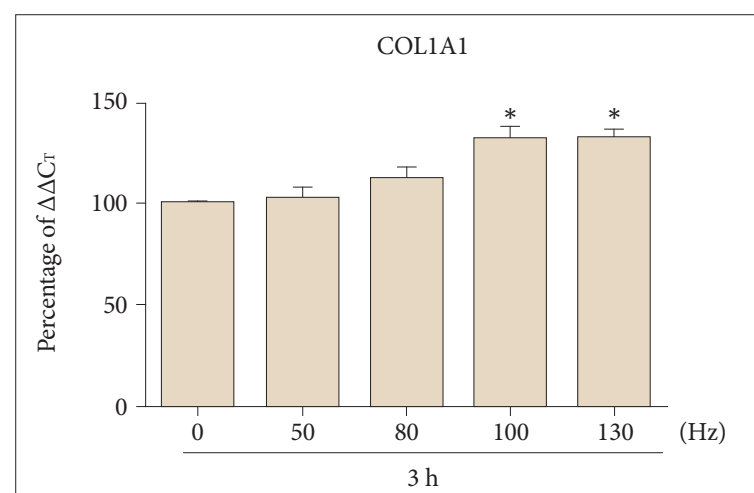

COL1A1

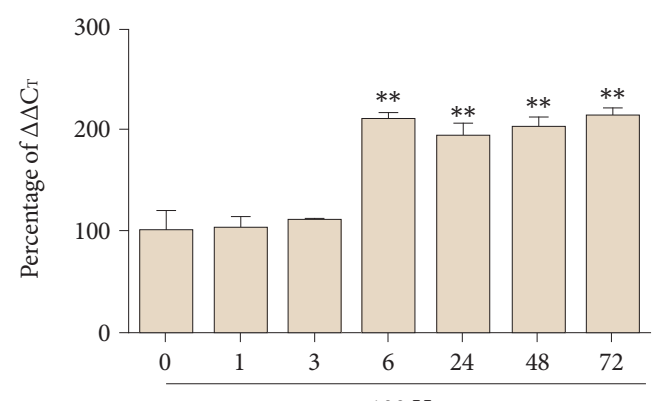

A

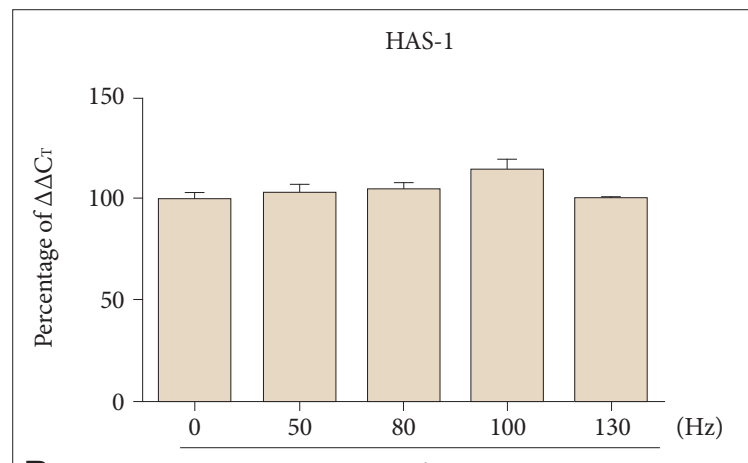

B

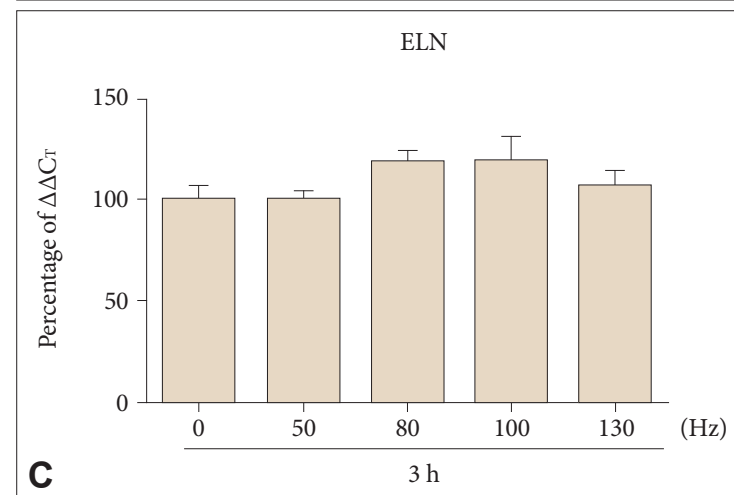

COL1A2

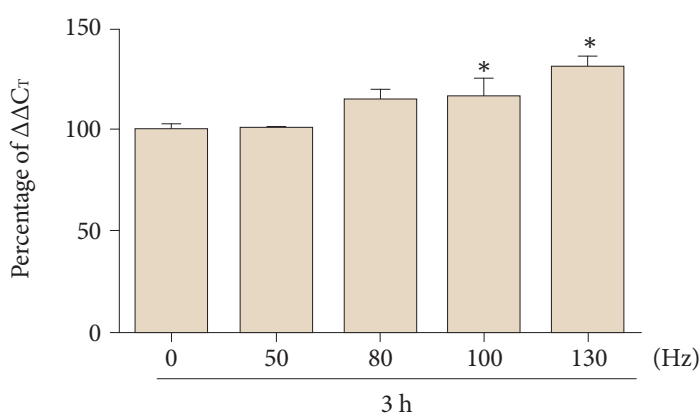

COL1A2

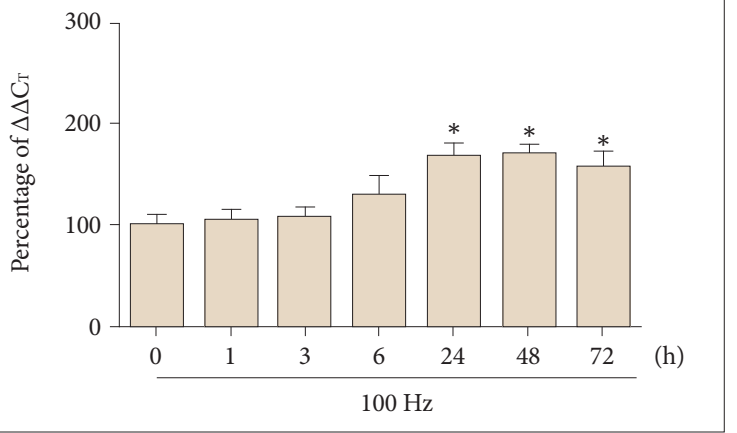

HAS-1

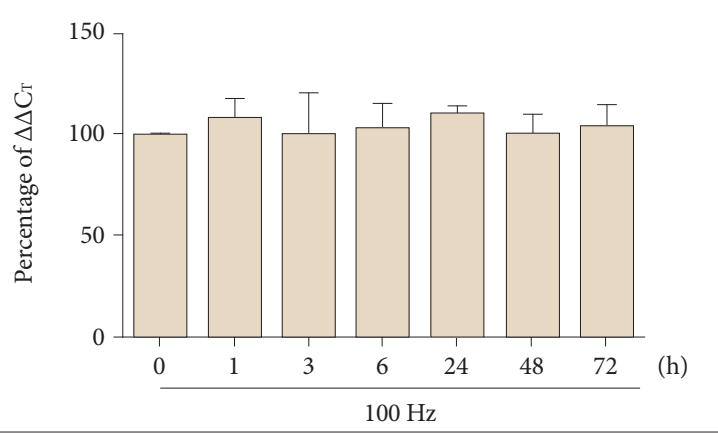

ELN

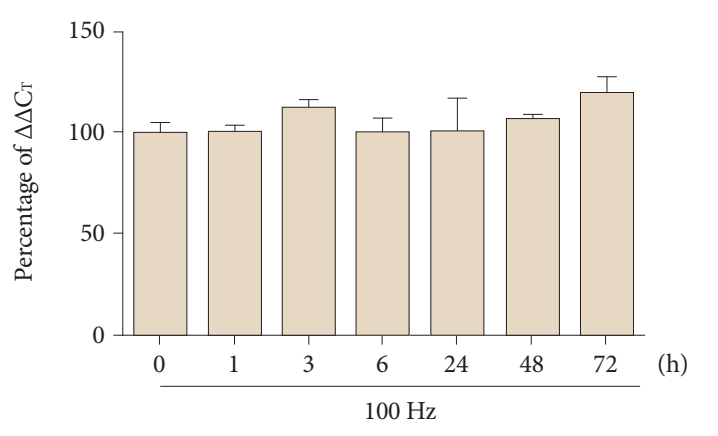

Fig. 4. Effects of vibratory stimulations on expression of ECM-related genes in hVFFs. Quantitative polymerase chain reaction analyses of genes encoding essential vocal fold ECMs. mRNA expression of COL1A1 and COL1A2 increased by dosage- and time-dependent manner with vibrating stimulation (A). However, mRNA expression of HAS-1 (B) and ELN (C) does not show statistically change with vibrating stimulation. The relative gene expression (fold change) was normalized to the respective housekeeping gene $\left(\beta\right.$ actin) control. ${ }^{*} p<0.05$, ${ }^{* *} p<0.001$. hVFF: human vocal fold fibrobloasts, ECM: extracellular matrix, COL1A1: collagen type I alpha 1, COL1A2: collagen type I alpha 2, HAS: hyaluronic acid synthase, ELN: elastin. 
극 노출 시간에 따른 통계적으로 유의한 차이를 확인할 수 없 었다(Fig. 4B and C).

\section{진동 자극이 성대 섬유아세포의 세포 성장 인자에 미치는 영향}

진동 자극이 성대 섬유아세포에서 fibroblast growth factor $1(\mathrm{FGF}-1)$ 과 transforming growth factor $\beta 1(\mathrm{TGF}-\beta 1)$ 의 발현에 어떠한 영향을 미치는지 real time-qPCR을 사용하 여 관찰하였다(Fig. 5). 진동 자극은 진동 주파수의 증가와 함께 $\mathrm{TGF}-\beta 1$ 와 $\mathrm{FGF}-1$ 의 mRNA를 발현시켰다. TGF- $\beta 1$ 은 $100 \sim 130 \mathrm{~Hz}$ 에서 가장 높은 발현을 보였다 $(\mathrm{p}<0.01)$. 또한 $100 \mathrm{~Hz}$ 의 일정한 진동 자극을 다양한 시간으로 유발한 결과 $\mathrm{TGF}$ 는 3시간 이후부터 발현이 증가하여 24시간에서 최고치 로 발현되고 그 발현은 72시간까지 유지된다 $(\mathrm{p}<0.001) . \mathrm{FGF}-1$ 는 $50 \mathrm{~Hz}$ 에서부터 mRNA 발현이 현저히 증가하여 $100 \mathrm{~Hz}$ 에서 가장 높은 발현을 보였다 $(\mathrm{p}<0.001)$. 또한 $100 \mathrm{~Hz}$ 의 일 정한 진동 자극을 다양한 시간으로 유발한 결과 $\mathrm{FGF}$ 는 3시 간 이후부터 발현이 증가하여 $(\mathrm{p}<0.05)$ 72시간까지 발현이 유 지되었다 $(\mathrm{p}<0.001)$.
진동 자극이 성대 섬유아세포의 염증성 신호 전달 경로에 미치는 영향

진동 자극에 의한 성대 섬유아세포의 세포외기질과 성장인 자의 변화 기전을 확인하기 위해 신호전달경로에 대한 연구를 시행하였다. Mitogen-activated protein kinases(MAPKs)의 활성화와 p65의 인산화를 Western blot으로 확인하여 $\mathrm{Nu}^{-}$ clear factor $\kappa \mathrm{B}(\mathrm{NF}-\kappa \mathrm{B})$ 의 전사가 활성화됨을 확인하고자 하 였다. 결과를 살펴보면 extracellular signal regulated $\mathrm{ki}^{-}$ nase(ERK)는 $80 \mathrm{~Hz}$ 이상의 주파수에서 인산화되었으며, p38 은 $100 \mathrm{~Hz}$ 에서 인산화되어 MAPKs 경로를 활성화시킴을 확 인하였다 $(\mathrm{p}<0.05)$ (Fig. 6A). Fig. $6 \mathrm{~A}$ 에서 인산화된 ERK와 $\mathrm{p} 38$ 에 의해 활성화된 MAPKs 신호 전달 경로는 결국 $\mathrm{p} 65$ 의 인산화를 통하여 $\mathrm{NF}-\kappa \mathrm{B}$ 전사 활성을 유도함을 확인하였다 $(\mathrm{p}<0.01)$ (Fig. 6B).

\section{고 찰}

성대는 반복적으로 진동하여 음성을 내는 특수한 기관이 다. 이러한 성대의 진동하는 특성을 반영하지 않은 생체 외(in

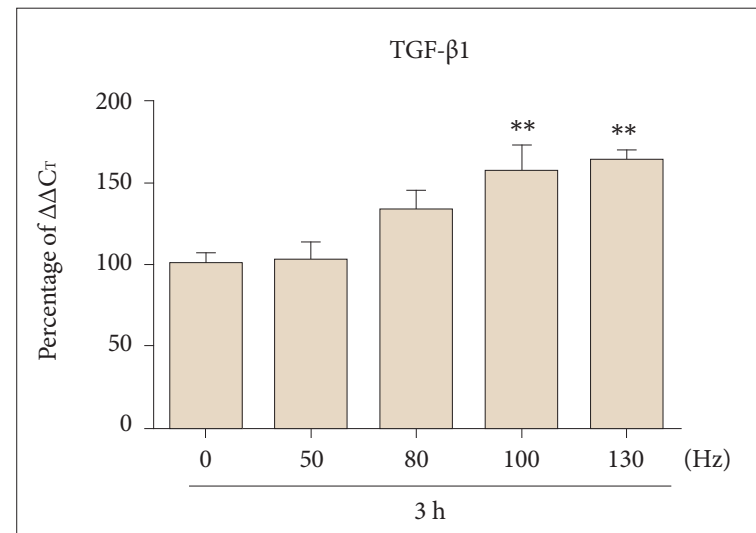

TGF- $\beta 1$

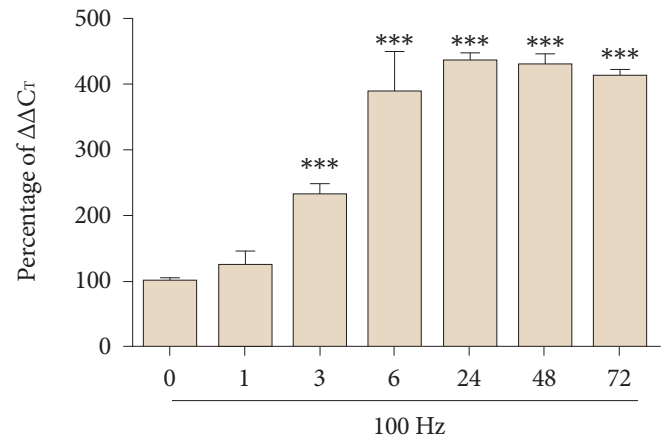

FGF-1

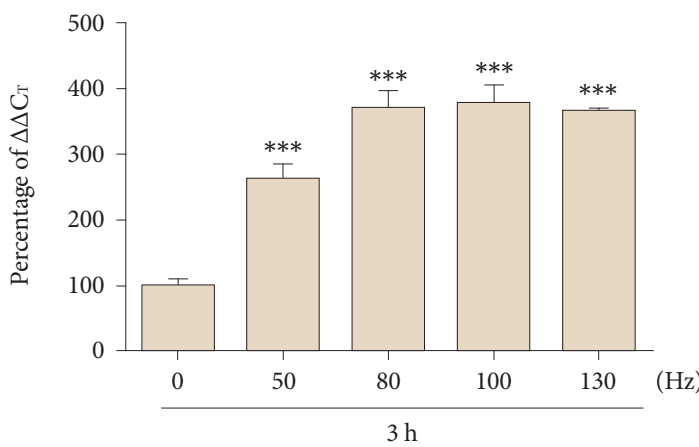

FGF-1

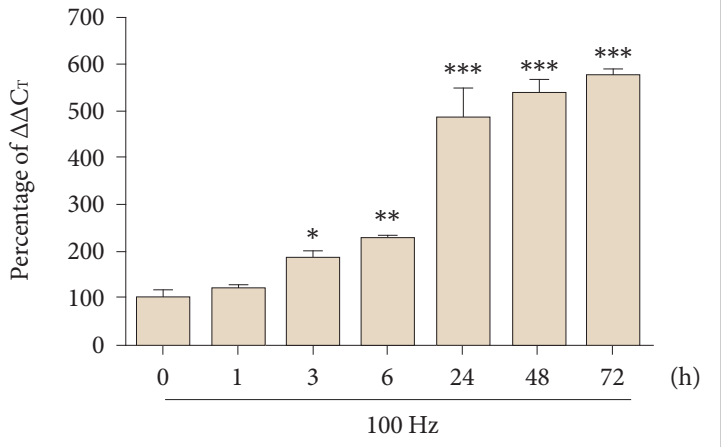

Fig. 5. Effects of vibratory stimulations on expression of growth factors in human vocal fold fibrobloasts. Quantitative polymerase chain reaction analyses of genes encoding essential vocal fold extracellular matrix. mRNA expression of TGF- $\beta 1$ and FGF-1 increased by dosageand time-dependent manner with vibrating stimulation The relative gene expression (fold change) was normalized to the respective housekeeping gene ( $\beta$ actin) control. ${ }^{*} p<0.05,{ }^{* *} p<0.01,{ }^{* * *} p<0.001$. TGF: transforming growth factor, FGF: fibroblast growth factor. 

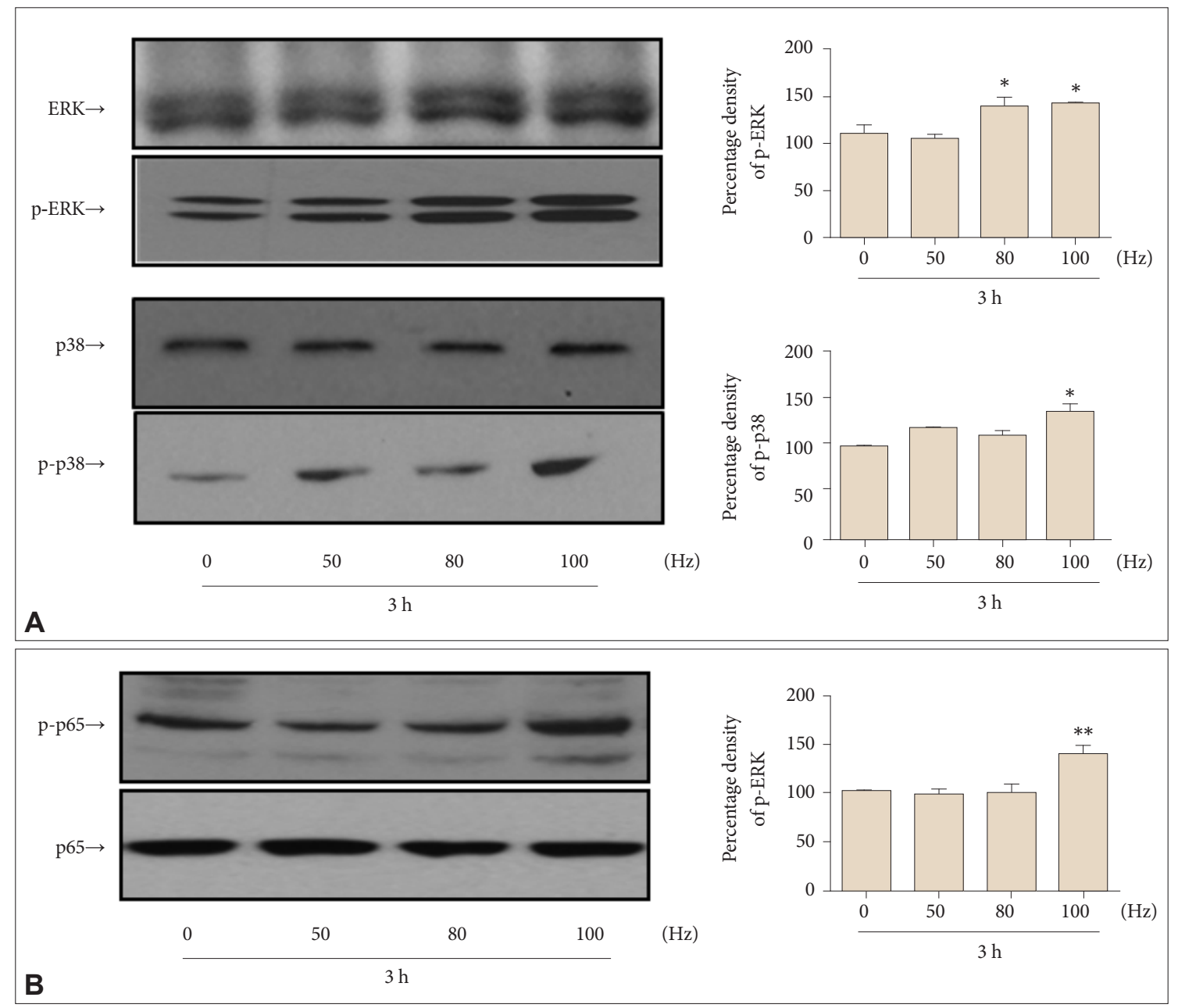

Fig. 6. Effects of vibratory stimulations on transcriptional activity of NF-kB in human vocal fold fibrobloasts. Western blot analyses of mitogenactivated protein kinases and NF-KB p65 phosphorylation in vocal fold. Phosphorylation level of ERK and p38 increased by vibrating stimulation. The relative phosphorylation was normalized to the respective total ERK and p38 control (A). Phosphorylation level of p65 increased by vibrating stimulation. The relative phosphorylation was normalized to the respective p65 control (B). ${ }^{*} p<0.05,{ }^{* *} p<0.01$. NF: nuclear factor, ERK: extracellular signal regulated kinase.

vitro) 연구는 실제 임상에서 다른 효과를 보일 수 있다. 생체 외 연구에서 성대 조직의 기능을 고려한 진동 자극형 생물반 응기 연구는 성대 미세 환경의 재현에 반드시 필요한 연구이다. 이전의 여러 연구에서 다양한 방법으로 성대 세포와 $\mathrm{ECM}$ 연 구에 관련된 생물반응기를 개발하였다. Webb 등[13]은 생물 반응기를 사용하여 $100 \mathrm{~Hz}$ 진동이 히알루론산 기반 하이드로 겔에서 배양된 피부 섬유아세포에 미치는 영향을 연구하였다. 그 외에 Kim 등[14]은 일정 시간의 자극을 주고 세포를 안정 화한 후 다시 자극을 주고 안정화하는 반복 자극을 실제의 사 람 발성과 비슷한 진동 자극을 가하는 방법으로 섬유아세포 의 반응을 연구하였다. 진동 자극을 유발하는 생물 반응기를 이용한 생체 외 연구는 성대의 특성을 고려한 음성 연구에 중 요한 역할을 한다고 할 수 있다.

본 연구에서는 작은 모터의 회전력을 진동으로 변화시킨
생물반응기로 매우 단순하지만, 성대 섬유아세포에 적용한 결 과 세포 사멸 없이 세포를 자극하는 적절한 진동 자극 주파수 와 진동 시간을 확립하였다. 진동 자극에 의해 성대 섬유아세 포에서 세포외기질 관련 단백질의 유전자 발현이 변화하였다. 본 연구에서 콜라겐의 두 가지 아형인 COL1A1과 COL1A2 의 발현은 100 130 Hz의 주파수에서 6시간 이후 유의하게 증가하였으나 $\mathrm{HAS}-1$ 과 ELN의 발현은 같은 진동 주파수와 진동 자극 노출 시간에 따른 통계적으로 유의한 차이를 확인 할 수 없었다. 성대 섬유아세포에 저주파 자극을 시행한 연구 에서 72시간보다 짧은 시간의 자극에서는 HAS와 ELN은 변 화가 없었지만, 72 시간보다 장시간 자극을 하는 경우 HAS와 ELN이 증가하였다[15,16]. 본 연구에서 HAS-1과 ELN의 변 화가 없는 이유는 자극 시간이 짧은 것이 그 이유로 생각된다.

진동 자극은 세포외기질에 영향을 주는 성장 인자, 특히 
$\mathrm{TGF}-\beta 1, \mathrm{FGF}$ 의 발현이 진동 초기부터 유의하게 증가하였다. 이는 세포외기질 구성 요소인 콜라겐 축적보다 세포의 성장 인 자 변화가 초기 단계 발생하는 것을 의미한다. 이는 또한 TGF$\beta 1, \mathrm{FGF}-1$ 의 증가는 콜라겐 분비를 증가시키기 때문에, 세포 외기질의 $\mathrm{COL} 1 \mathrm{~A} 1$ 과 $\mathrm{COL} 1 \mathrm{~A} 2$ 의 발현 증가와도 일치하는 결 과이다. 성대 섬유아세포는 $205 \mathrm{~Hz}$ 주파수에서 2초 간격의 반복하여 진동 자극을 한 경우, 세포 증식능에는 영향이 없었 으나 $\mathrm{EGF}, \mathrm{FGF}, \mathrm{TGF}$ 등의 성장 인자의 유전자 발현이 증가 하였다[14]. Wolchok 등[17]의 연구에 의하면 $100 \mathrm{~Hz}$ 의 진동 자극에 의해 $\mathrm{TGF}-\beta 1$ 의 발현이 증가하여 콜라겐을 포함하는 세포외기질 관련 유전자의 발현이 증가한다고 하였다. 이러한 연구는 본 연구와 일치하는 결과이다.

본 연구에서 진동 자극에 의해 성대 섬유아세포에서 중요한 신호전달경로인 $\mathrm{NF}-\kappa \mathrm{B}$ 및 $\mathrm{MAPKs}$ 의 활성화가 유도됨을 확 인하였다. Tong 등[18]은 중간엽 줄기세포에서 외부의 다양한 기계적 자극에 의해 ERK가 활성화된다고 하였다. 그리고 골 세포에서는 진동 자극에 의해 $\mathrm{NF}-\kappa \mathrm{B}$ 가 활성화된다는 보고 가 있다[19]. 진동 자극 후 섬유아세포의 변화는 MAPK/NF$\kappa \mathrm{B}$ 경로를 통해 세포외기질에 영향을 주는 것으로 생각된다.

본 연구자들이 개발한 생물반응기는 만들기 쉬운 단순한 형태이지만 여러 가지 단점을 가지고 있다. 첫째, 연구자들이 개발한 생물반응기의 한계 때문에 $130 \mathrm{~Hz}$ 이하의 진동에서 만 실험을 하여 실제의 성대 진동을 정확하게 반영하지 못하 였다. 둘째, 진동 시간과 주파수는 조절이 가능하였지만, 진폭 의 조절이 힘들었다. 실제 성대의 진폭을 반영하는 진폭 조절 이 가능한 생물반응기의 개발이 필요할 것으로 생각된다. 셋 째, 성대 조직과 유사한 기계적 특성을 나타내는 3D 생체 모 방 매트릭스에서 배양된 세포에서 진동 자극을 유도하는 연 구가 필요할 것으로 생각된다. 또한 기계적 특성을 나타내는 $3 \mathrm{D}$ 생체 모방 매트릭스에서 배양된 세포에 대한 진동 자극의 효과를 연구하고자 한다.

\section{결 론}

성대 섬유아세포에서 진동 자극은 콜라겐의 합성과 TGF, $\mathrm{FGF}$ 의 합성을 증가시킨다. 이러한 기전은 $\mathrm{NF}-\kappa \mathrm{B}$ 및 MAPKs 의 활성화에 의한 것으로 생각된다.

중심 단어: 생물반응기, 진동자극, 성대세포주, 콜라겐.

\section{Acknowledgments}

This work was supported by the National Research Foundation of Korea (NRF) grant funded by the Korea government (Ministry of Science, ICT \& Future Planning) (No. 2016R1D1A3B01015539) and clinical research grant from Pusan National University Hospital in 2021.
Conflicts of Interest

The authors have no financial conflicts of interest.

\section{Authors' Contribution}

Conceptualization: Ji Min Kim. Data curation: Ji Min Kim, Sung-Chan Shin. Formal analysis: Ji Min Kim, Jung Hoon Ro. Investigation: Ji Min Kim, Yong-Il Cheon. Methodology: Ji Min Kim, Jung Hoon Ro. Project administration: Byung-Joo Lee. Supervision: Byung-Joo Lee. Writing — original draft: Ji Min Kim, Hyun Keun Kwon. Writing_review \& editing: Sung-Chan Shin, Byung-Joo Lee. Approval of final manuscript: all authors.

\section{REFERENCES}

1. Gray SD. Cellular physiology of the vocal folds. Otolaryngol Clin North Am 2000;33(4):679-98.

2. Catten M, Gray SD, Hammond TH, Zhou R, Hammond E. Analysis of cellular location and concentration in vocal fold lamina propria. Otolaryngol Head Neck Surg 1998;118(5):663-7.

3. Hartnick CJ, Rehbar R, Prasad V. Development and maturation of the pediatric human vocal fold lamina propria. Laryngoscope 2005; 115(1):4-15.

4. Zerdoum AB, Tong Z, Bachman B, Jia X. Construction and characterization of a novel vocal fold bioreactor. J Vis Exp 2014;(90):e51594.

5. Lee BJ. Tissue engineering for treatment of vocal fold scar. J Clin Otolaryngol Head Neck Surg 2010;21(2):191-8.

6. Zhang K, Siegmund T, Chan RW. A two-layer composite model of the vocal fold lamina propria for fundamental frequency regulation. J Acoust Soc Am 2007;122:1090-101.

7. Wang JH, Thampatty BP. An introductory review of cell mechanobiology. Biomech Model Mechanobiol 2006;5(1):1-16.

8. Kim DH, Wong PK, Park J, Levchenko A, Sun Y. Microengineered platforms for cell mechanobiology. Annu Rev Biomed Eng 2009; 11:203-33.

9. Webb K, Hitchcock RW, Smeal RM, Li W, Gray SD, Tresco PA. Cyclic strain increases fibroblast proliferation, matrix accumulation, and elastic modulus of fibroblast-seeded polyurethane constructs. J Biomech 2006;39(6):1136-44.

10. Gray SD, Hirano M, Sato K. Molecular and cellular structure of vocal fold tissue. In: Titze IR, editor. Vocal fold physiology: frontiers in basic science. San Diego, CA: Singular Publishing Group Inc.;1993.

11. Titze IR, Hitchcock RW, Broadhead K, Webb K, Li W, Gray SD, et al. Design and validation of a bioreactor for engineering vocal fold tissues under combined tensile and vibrational stresses. J Biomech 2004; 37(10):1521-9.

12. Thibeault SL, Li W, Bartley S. A method for identification of vocal fold lamina propria fibroblasts in culture. Otolaryngol Head Neck Surg 2008;139(6):816-22.

13. Webb K, Hitchcock RW, Smeal RM, Li W, Gray SD, Tresco PA. Cyclic strain increases fibroblast proliferation, matrix accumulation, and elastic modulus of fibroblast-seeded polyurethane constructs. J Biomech 2006;39(6):1136-44.

14. Kim D, Lee S, Lim JY, Kwon S. Characteristics and responses of human vocal fold cells in a vibrational culture model. Laryngoscope 2018;128(7):E258-64.

15. Kutty JK, Webb K. Vibration stimulates vocal mucosa-like matrix expression by hydrogel-encapsulated fibroblasts. J Tissue Eng Regen Med 2010;4(1):62-72.

16. Tong Z, Duncan RL, Jia X. Modulating the behaviors of mesenchymal stem cells via the combination of high-frequency vibratory stimulations and fibrous scaffolds. Tissue Eng Part A 2013;19(15-16):186278.

17. Wolchok JC, Brokopp C, Underwood CJ, Tresco PA. The effect of bioreactor induced vibrational stimulation on extracellular matrix pro- 
duction from human derived fibroblasts. Biomaterials 2009;30(3): 327-35.

18. Tong Z, Zerdoum AB, Duncan RL, Jia X. Dynamic vibration cooperates with connective tissue growth factor to modulate stem cell behav- iors. Tissue Eng Part A 2014;20(13-14):1922-34.

19. Sakamoto M, Fukunaga T, Sasaki K, Seiryu M, Yoshizawa M, Takeshita $\mathrm{N}$, et al. Vibration enhances osteoclastogenesis by inducing RANKL expression via NF- $\kappa B$ signaling in osteocytes. Bone 2019;123:56-66. 